\title{
Information and Communication Technologies(ICT): A Panacea to Achieving Effective Goals in Institutional Administration \\ Liverpool E. Onyije
}

\author{
Registrar, Federal College of Education (Technical) Omoku, Rivers State, Nigeria \\ Jacinta A. Opara \\ President, African Association for Teaching and Learning, Accra-Ghana
}

\section{Doi:10.5901/mjss.2013.v4n13p227}

\begin{abstract}
This paper examines the use of Information and Communication Technology (ICT) by institutional administrators for effective administration. The paper states the need for effective use of ICT by institutional administrators in maintaining and controlling according to policies laid down by the governing bodies of the institution. He has to plan in his capacity as an administrator in ensuring effective institutional services. The paper highlights various ICT resources that can be used for effective and efficient institutional administration. It also states some of the benefits and challenges of the use of ICT institutional administration. It is the contention of this paper that though using ICT in Nigerian institutional administration may seem difficult, it is imperative to take advantage and invest in these ICTs to deal with the huge pressure faced in the institutional administration. The remarks highlights the need for infrastructure and how political will push ICT ahead.
\end{abstract}

Keywords: Information and Communication Technology, Administration, Effective and Efficient, Institution, Political

\section{Introduction}

Institutional policy agendas in Nigeria are increasing focusing on the need to integrate information and communication technology (ICT) in our institutional system. These technologies provide an opportunity for institutional administrators to manage school information more efficiently. Institutional administrators are considered to be the central forces in tapping the learning opportunities created by the introduction of ICTs. They hold the key to what and how teaching and learning take place at schools and in the communities (Mankilik and Agbo, 2006). Indeed, ICT holds out the opportunity to revolutionize teaching methods, expand access to quality education and improve the management of institutional system (WorldBank, 2002).

Potentially, the principle factor for onset, smooth running and achievement in institutional goal is effective and realistic administration. Administration according to Hornby (2002) is perceived as activity done in order to plan, organise and successfully run a business, school or other institution, a process or act of organizing the way that something is done. Administration according to Edem (2006) involves planning activities which aim at the fulfilment of the goals of a particular organization or institution. It calls for the ability of the administrators to make the right decisions to fulfil the required goals. In institutional setting therefore, administration has been extended as a service activity or tool through which the fundamental objectives of the institutional process may be more optimize efficiently when allocating human and material resources as well as to make the best use of existing resources.

\section{The Concept of Information and Communication Technology in Institutional Administration}

Information and communication technology (ICT) has been defined by various scholars from different perspectives. Mansell and Silverstone (1996) defined ICT to include electronic network-embodying complex hardware and softwarelinked by a vast array of technical protocol. It is a generic concept which refers to technologies by which various forms of information are collected, stored and edited (SER, 1977). It is also explained as multi-media application involving a combination of data carriers such as CD - ROM, Video, Floppy disk, internet and other software in which possibility for interactive communication is offered (Smeet, 1996). ICT, however are facilities, tools or resources that could be used to process, store, preserve, access, retrieve and disseminate information with ease. It could be seen as the engine for 
growth and tool for empowerment, with profound implications for education, change and socio-economic development.

The dream of any institution in an effective and efficient managerial process is to accomplish their needs and goals. Ohakwe and Okwuanaso (2006) contented that the knowledge of computer application software's such as spreadsheet, excel, computer-aided design, and database are important skills in institutional administration. The complexity of institutional system requires more demand from the institutional administrators in processing of relevant data in an attempt to provide information for the governing bodies, institution and other institutional agencies for decision making towards quality assurance and transformational development.

Institutional administrators need to have basic information on students and teacher flows, institutional supplies, and how much the system is spending on various inputs, in order to make the most basic resource allocation decisions. In this context, however, for institutional administrators to deal with the huge pressure faced in the institutional administration, Iwu (2003) categorized the use of ICTs into the following for effective and efficient services:

i. Sensing Technologies: These equipment gather data and translate them into form that can be understood by the computer, such as scanners, sensors, keyboard, mouse, electronic pen, barcode sensors or readers, touch of digital boards, voice recognition system etc. They could be used by the institutional administrators to do computation and processing of paper work. These sensory technologies gather data to do complex computation very rapidly and accurately. Similarly, through word processing they enable them to draft, revise and produce reports of high quality at least in terms of presentation without much hard labour, frustration and waste of time.

ii. Communication Technologies: These are equipment that the institutional administrators could use to transfer information from the sources to users. They are capable of overcoming natural barriers to information transfer like speed and distance. These includes; facsimile machines (fax), telephone, electronic mail, telecommunication system, teleconferencing, electronic bulleting boards etc. In Nigeria especially in the Niger Delta region, there are lots small islands, and sometimes the institutional administrators in the region work together. To travel to meetings are very expensive, so virtual meetings can be use instead. They use free software such as skype. It is a useful way of communicating and saves time, risk and a lot of money.

iii. Display Technologies: These are output devices that form the interface between sensing, communication and analysing technologies and human user. These include; computer screen, printers, television etc. At first, some of the display technologies are seen as luxury but some of the institutional administrators after realizing what it could do began to see it as a necessity. Every computer in the institution has to be connected to the internet. The office of the institutional administrators is open to the public, to researchers, staff, students and parents wanting information about the institution. They can find all of that information on the internet. This makes the work easier by reducing the flow of people through the office, and improves access to information.

iv. Analysis Technologies: These are the technologies that help the institutional administrator to investigate of query of data, analysis and in-depth query for answers from simple to complex phenomena in administrative procedures. A complete set of a computer system could be a micro, mini, mainframe or super scamper. ICT has changed the way in which institutional administrators collect and analyze data. For instance, the use of Access, excel and other simple applications to collect, store and analyse information. They may also need some sophisticated packages like SPSS (statistical package for the social science). This is to improve the timeliness and volume of information in implementing an institutional management information system.

v. Storage Technologies: These technologies facilitate the efficient and effective storage of information in a form that can be easily accessed. They include: magnetic tapes, disks, optical disks cassettes etc.

\section{The Role of ICT in Institutional Administration}

Based on the above types and use of ICTs, the institutional administrator harmonized appropriately both task and human relationship in order to gain the confidence of the institution. He uses the ICTs to improve administrative efficiency such as:

1) Organization of information: Institution administrators need to have basic information on students and teacher flows. For example, categorize data on student/staff by sex, class, state of origin, performance in schools etc. They organises data into an easily accessible format and can be easily stored and retrieved from the micro computer. And also that of the staff, facilities and finances can be similarly treated.

2) Computation and processing of paper work: They could use this to map out such activities of the semester from day one to last day of closing for break. The number of weeks for revision, real teaching, conducting of 
continuous assessment tests, examination periods, and when the result could be released to students. Activities such as stipulated time for teaching practice and student industrial work experience scheme (SIWES).

The use of Access, excel and other simple applications to collect, store and analyse information on teachers assigned roles such as setting up of question papers, marking, moderation etc. He keeps records of events, enhancement of effective happening in the institution, issues out notices of meeting for staff, students and parents which could all be accessible through ICTs.

3) Enhancement of effective communication: This could involve the use of tel, fax and communication facilities with the installation of computers and internets communication is made easier. Iwu and Ike (2009) opined that ICT has rendered international boundaries irrelevant since many modern activities cut across international frontiers. We now live in a boundless world that is becoming a smaller place, due to the recent development in ICT. Institutional administrators uses ICT for improved communication as a process of transforming thoughts, the sharing and imparting of information, growing and receiving and understanding of message within a network of independent relationship.

4) Enhancement of planning: The database is established through the organization of data on various elements of the institution such as student, staff, resources etc. This could be used by institutional administrator to plan and make decisions on the basis of accurate and readily available facts. He budgets the school expenditure and plans for replacement of both obsolete and repairs of broken down equipment or institutional facilities.

5) Improvement of monitoring: Institutional administrators use microcomputers in monitoring various areas in the institutional system, such as the uses of continuous monitoring and assessment of students learning and achievement in the institution. Campbell and sellburn (2002) pointed out that ICT can be valuable for storing and analyzing data on education indicators, students' assessments, educational, human and material resources, and cost and finance.

6) Managed instruction: This is an approach by the institutional administrators to use computer in scheduling courses/subjects, space, installation, inventory and personnel control, recording and reporting attendance, school accounting, storage and retrieval of student information marks management. This is capable of generating the demographic data of students and institutions staff, production of results online, retrieving on lecture timetable online and enlisting of courses and registration through online.

\section{The Challenges of the use of ICT in Institutional Administration}

Most higher institutions in Nigeria are still using the traditional paper based documentation system which slows down the method of processing of documents, filling system in keeping records, and delay processing of documents in and out of the schools. Even with various benefits of ICT to all facets of human life, there are still challenges to its utilization in developing countries like Nigeria. Gbenga (2006) stated that many institutions, in Nigeria do not have computers and have no access to the internet, which is an important requirement for supporting networking for learners and teachers as well as higher institutions.

In institutional administration, there is need to exchange information between the lower echelons and the central level. This is a problem in Nigeria. Some of the schools and departments are far from centre. There is no well-developed ICT network, and the institutional system is suffering because of it. The infrastructure is not there; it needs investment and commitment from the government. The problem of poor infrastructural facilities especially erratic power supply has been the major cause of poor usage of ICT in institutional administration.

The institutional administrators need to raise awareness about the potential of ICTs, particularly to improve communication. At the moment, people are not ready. They are not exposed to new technology and institutional administrators do not provide training for them. They do not have expertise in the field of ICT.

In recent years there has been a move towards introducing ICT in every teacher training programme. Even private higher institutions are required to have ICT departments. Designing a separate ICT policy for institutions will require special attention, but it is imperative for countries like Nigeria. As identified by Gambari and Chike-Okoli (2007) is that, Nigeria is not fully part of global University System (GUS). The GUS is an initiative to educate students through a satellite of wireless telecommunication infrastructure, mostly using internet.

However, spending on ICT differ considerably between countries and is related to their level of development. Lack of proper acquisition of ICT resulting in low utility, low ICT skills, inadequate supporting infrastructure and high cost of maintaining and servicing equipment are all challenges in the institutional administrative activities. Unegbu (1999) stated 
that high cost of purchasing and replacing the ICT facilities and high cost of training and retaining staff resulting in low ICT skills on the part of the staff as a major challenge. There are inadequate technical/skill manpower in the area of ICT in Nigeria. Faulty equipment is abandoned because there is no knowledgeable staff to repair it.

In order to face some of the challenges, definitely new policies will be required. There should be policies to facilitate the use f ICT in the institutional administrative set up, to allow workers to develop their capabilities, and to improve work processes. There must also be policies at the institution level to better integrate ICT in the curriculum and to provide equal access to ICT for all students and staff.

There is need for policies to address the sustainability of ICT initiatives. The government should monitor effectively the policy on ICTs in Nigeria like NUNET, school-net etc. are not properly monitored. Sustainable policies, which are essential should be given the length of time needed to carry out the process/project.

Effective incorporation of ICT in teaching practices. This is best provided through in-service teacher training and staff development programmes for institutional administrators. School participating in the integra project received specific teacher training and had to design teaching proposals integrating ICT through seminars, workshops etc.

In addition, there should be proper access and connectivity, particularly in rural areas. This requires a concerted effort on the part of regulator, service providers and institutional administrators. The institutional administrators also need to maintain a good working environment for their staff, student and community as to promote ICT growth and maintenance. Too much attention has been paid to the technology itself and not enough to its application to the institutional system. Perhaps incorporating ICT in institutions should be considered as a process of cultural change within the institution, as it implies new ways of seeing and being seen, as well as new ways of thinking and acting.

Finally, lack of finance prevents us from making as much progress as we would like. For example many of our institutions do not have computers. There are always conflicting priorities when financing is scarce. To effectively integrate information and communication technologies in our higher institutions, it is important first to commit more resources, and second to use rational criteria when allocating equipment and providing training and staff development for institutional administrators.

\section{Conclusion}

It is quite obvious that for institutional administrators to function efficiently and the institution to effectively pursue its academic excellence, the use of ICT is needed. Based on this, several measures are necessary to improve the use of ICT in our higher institutions. Such measures as creating ICT awareness, and effective training of the institutional administrators as well as making available necessary ICT facilities

\section{References}

Annual socio-economic Report on Access to ICT (2011). Report on distribution of ownership and Access to ICT www.nigeriastat.gov.ng

Arunachalam, S. (2005) Information and knowledge in the age of electronic communication. A developing country perspective: http://www.bytesford .org

Eden, D. A. (2006) Introduction to Educational Administration in Nigeria Ibadan: spectrum Book Ltd.

Fanant J. S. (1988) Principles and practice of Education revised edition Hong Kong. Sheck Wah Tong printing press Ltd.

Gambari, A. I and Chike-Okoli (2007) Availability and utilization of ICT facilities in higher institution in Niger State, Nigeria. Information Technologist vol. 4 No. I

Gbenga, A. (2006) ICT and web mining techniques. A paper presented at ETF capacity building workshop held at University of Illorin.

Hornby, A. S. (2002) Oxford Advance Learner's Dictionary: Oxford University press.

Iwu, A. O. and Ike, G. A (2009) Information and communication technology and

Programmed Instruction for the attainment of educational goals in Nigeria's econdary schools. Journal of the Nigeria Association for educational media and technology (I) September, 2009.

Mansell, R. and Silver Stone, R. (1996) Communication by Design. The politics of ICTs: Ibadan. Oxfor University press.

Mankilik, M. and Agbo, F. O. (2006) Integrating information and communication technology (ICT) in teacher's training programme. A paper presented at the $27^{\text {th }}$ annual conference of the Nigeria Association for Educational Media Technology (NAEMT) held at Jos, $29^{\text {th }}$ August $-1^{\text {st }}$ September.

Ohakwe, S. and Okwuanaso, S. (2006) The access centre: improving outcomes for all Students K-8 Department of Education programme office of special education programmes Washington DC. www.inodev.og.

SER (1997) ICT and arbeid: advise informative-encommunication technologic enarbeid Den Haaf: SER Social - Economiche Raad.

Smeet E. F. (1996) Outbrak ons de verbeelding? If you can dream it, you can do it. Bijdrage Liber Amicorum Vrienden Van Jan Geurts.

Unegbu, M. C. (1999) Impact Assessment of IT on the performance of the Nigerian manufacturing sector. A project submitted to African Regional Centre for information science, university of Ibadan. www.iipe-buenosaires.org.ar/diffusion/publicaciones/index.asp

Uyanga, E. R. (1989) Educational administration and planning. A collaboration Approach. Agape press, Lagos.

World Bank (2002) World science report on Information and Communication Technology Washington D.C. 